\title{
Chinese Belt and Road Initiative - the perspective of the Federal Republic of Germany
}

\section{Introduction}

The aim of the article is to show what attitude is expressed by the Federal Republic of Germany towards the Chinese Belt and Road Initiative (BRI) on the level of state and non-state actors. It is important, since Germany is China's key trading partner in the European Union, and at the same time the People's Republic of China (PRC) is the most valuable economic partner for Germany since 2017. It seems, therefore, that the perception of the Chinese strategy of international development and building economic, political and cultural connections by the Germans is of the highest importance for understanding current German-Chinese relations and their consequences for the whole European Community.

The article is divided into an introductory part presenting the basis of the current cooperation between Germany and the PRC, followed by an explanation of the theoretical approach, and analyse of the German perception of the New Silk Road Initiative $^{1}$ in two different phases: first, in the "fluctuation phase" (2013-2016), and then in the current "phase of conflict and cooperation" (2016-), in which the model of political cooperation and the awareness of problem areas in bilateral relations developed. The starting point is the reference to the liberal theories in international relations which emphasize the role of state-society connections. They emphasize the importance of quality analysis tools in the global economy as an increasing number of interdependencies, being the result of liberalization of various forms of international economic cooperation, and indicate the increase in the rank of non-governmental actors in the process of building bi- and multilateral relations (including mass media, interest groups and public opinion). The analysis is concluded with a short theoretical summary as well as political recommendations regarding German-Chinese relations.

\section{The Belt and Road Initiative and the German-Chinese cooperation}

The term "Silk Road" was created in the $19^{\text {th }}$ century by the German traveler and geographer Ferdinand von Richthofen, who in this way defined the former trade route connecting China with the Middle East and Europe. However, the route lost its impor-

${ }^{1}$ The terms New Silk Road and Belt and Road Initiative are used interchangeably in the text because in Polish literature on this subject it is assumed to use both names. In English and German literature, however, the term Belt and Road Initiative (BRI) is most often used. 
tance after the discovery of the sea route to China in the $17^{\text {th }}$ century and did not gain widespread recognition until the $20^{\text {th }}$ century. Today, this ancient project connecting the Eurasian regions with the eastern and western parts of the world, stretching from Japan and the Korean Peninsula to the Mediterranean, gains a new dimension. As a concept of the Silk Road Economic Belt (SREB) it was presented by the Chinese leader Xi Jinping during his visit to Kazakhstan in September 2013. In a speech delivered at Nazarbayev University, President Xi suggested that China and Central Asia should closely cooperate with each other to build a new dimension of the Silk Road. At this moment, Xi mentioned this strategic vision for the first time.

The idea of creating the New Silk Road was concretised by the president of the Peoples Republic of China in October 2013, when he proposed to build an agreement between China and the countries belonging to the Association of South-East Asian Nations (ASEAN) and presented the assumptions for the project of the Maritime Silk Road (MSR). Therefore, the plan was based on two pillars - the land and maritime Silk Road - and is nowadays considered as one of the largest infrastructural and investment ideas in history. It covers almost 70 countries, that are inhabited by $65 \%$ of the world's population (4.4 billion people) and are responsible for $40 \%$ of global GDP in 2017 (Campbell, 2017). The project focuses on the expansion of the infrastructure network connecting China and the countries of Central Asia, the Middle East, Africa and Europe in order to create favorable cooperation opportunities in the field of infrastructure and financial projects. And although its original name was One Belt One Road (OBOR), in subsequent years it was changed into the Belt and Road Initiative (Bērziņa-Čerenkova, 2016).

Although the name has changed, the development strategy itself has not altered and since 2013 it has aroused great interest among European and Asian countries. It is not different in the Federal Republic of Germany, which - according to the analysis of the German think tank Mercator Institute for China Studies (Merics) - is considered as a country in which Chinese investments are the most intense (Wübbeke et al., 2016). This should not come as a surprise - Germany is currently the most important trading partner for China on the European continent, and German-Chinese relations remain one of the most complex relations between the PRC and the EU member states. The bilateral dialogue covers 80 cooperation mechanisms complemented by intergovernmental consultations and bilateral talks on foreign and security policy. In the foreground, however, there is economic cooperation - already in 1978, the Federal Republic was in the fourth place among global and in the first place among European trade partners for China. Today, Germany is by far the most important trade partner for China in Europe. On the other hand, China is the most significant economic partner for Germany, both in Asia and around the world, because the PRC overtook the place of the United States and France, and took a leading position in trade relations with Germany. The level of German direct investment in China amounted to 69.5 billion EUR in 2015, while the level of Chinese direct investment increased six times since 2004 and amounted to 2.2 billion EUR at the end of 2015. Meanwhile, bilateral trade in 2016 amounted to almost 170 billion EUR - 76 billion EUR came from German exports to China and almost 94 billion EUR from Chinese exports to Germany, and in 2017 Germany and China reached a turnover of 186.6 billion EUR (Hanemann, Huotari, 2017). 
Germany is considered to be the leading Chinese partner in Europe, distinguished by its key role in European politics and high technological innovation. Moreover the Chinese are aware that Germany is the undisputed leader of the European Union in both economic and political terms - especially after 2010, when the economic crisis in the countries of the European South began, and Germany was the only country that was able to take responsibility for the fate of the entire Eurozone. In fact, the Germans emerged as leaders of Euroland and the European Union as a whole, although Beijing was aware that they were not able to completely dominate the Community or transform into a world power.

However, recent months of cooperation between China and Germany indicate that these countries are beginning to enter the phase of a difficult friendship. This is primarily the result of the Chinese investment offensive in Germany. According to the EY consulting company, Chinese investors spent 12.2 billion EUR in 2017 for the purchase of German companies, what is an increase of 9\% compared to 2016 and the largest ever expenditure in this area (EY, 2018, p. 8). Investors from the Middle Kingdom are especially fond of enterprises operating in the electromechanical and chemical industry, which causes critical opinions in the industry, since the representatives of the German economy complained in recent years about the growing purchases of high-tech companies by Chinese entrepreneurs. However, scarcely taking over the leader in the field of robotics, Kuka, in 2016 as well as buying shares of the KraussMaffei machine industry company and shares of the renewable energy concern EEW Energy (which, until now, was the most expensive acquisition of a German company by a Chinese investor - 1.4 billion EUR) (dpa, 2016), caused widespread discussion in German political and social circles (Popławski, 2017, pp. 4-5).

The takeovers of companies by Chinese investors show that Germany has difficulties in assertively defending its interests in bilateral relations with China. The Federal Ministry of Economy and Energy admitted that China is on its way to become "the largest economy in the world and one of the largest geopolitical players in the $21^{\text {st }}$ century," and - as the Minister of State Matthias Machnig emphasized - "after two hundred years of national isolation and marginalization they want to get back to the top." Thanks to the initiatives undertaken under the aegis of the Belt and Road, China wants to become an economic superpower (Dams, Grabitz, 2018). This expansion of the PRC may pose a threat to the high position of the European Union and some of its member states. Thus, the Germans are looking at the New Silk Road concept with great interest, but also with caution.

Taking all this into account the following points, which play a primary role in German-Chinese relations, should be taken into consideration:

- favor of closer relations with China;

- China's ability to exploit Germany for its particular interests;

- occurrence of conflicting areas with the interests of the EU and European countries (also non-EU-states):

- the meaning of 16+1 Initiative;

- the (very diverse) interests of all member states of the EU towards China.

The lack of compliance of European countries with respect to the Asian superpower's activity was evident mainly in discussions in the European Union, including 
granting China the market economy status, the threat of price dumping and the introduction of EU anti-dumping duties on Chinese products (solar panels, Chinese steel), as well as on the territorial dispute on the South China Sea. The discussion reflected the general tendency of European countries to compete for Chinese capital and investments at the expense of formulating one European strategy towards Asia. Germany, as the most economically connected country with the PRC among the EU member states, often held an undecided position towards Beijing. Yet now, since China's political and economic influence in Europe is growing, German politicians treat this development with concern and insist that the European Union should oppose the Chinese geopolitical strategy by creating its own projects for cooperation with the Middle Kingdom.

\section{Theoretical approach}

As it is well-argued by Brummer and Oppermann (Brummer, Oppermann, 2014, pp. 31-37) and pointed out by Harnisch (Harnisch, 2017), in the liberal analysis of foreign policy, the social interests in the distribution of values are transferred to the political system through assertive intermediary institutions (such as business associations and non-governmental organizations), and then, in accordance with the institutional participation opportunities (such as the number of institutional players represented by the political parties) to the governments of other states. Different priorities of political and economic values as well as assertiveness in government policy are applied (Moravcsik, 1997, pp. 513-553; Moravcsik, 2008, pp. 234-254) in order to explain the compatibility (complementarity) of these preferences with those of third countries. At the same time, it seems that idealistic and economic preferences, in particular their combination and prioritization, are a more credible explanation for the behaviors of the ruling elites than realism, power politics or geoeconomical approach (Kundnani, 2011, pp. 31-45).

With regard to German-Chinese relations, it should be noted that the German perception of cooperation with the PRC has so far been shaped by interest in mutual economic benefits and compliance with the international economic, commercial and investment order, but it is clear that the public opinion in the Federal Republic is beginning to play an increasingly important role in shaping relations with China, emphasizing the importance of not only economic cooperation, but also focusing on the issues of human and civil rights, ecology and animal rights.

From the perspective of liberal theory, one can find various answers to the question of how dependently or independently of social preferences the federal government can shape the foreign policy of the country. Following the arguments of Thomas RisseKappen (Risse-Kappen, 1991, pp. 479-512), the democratization of foreign policy by social democrats in the late 1960s changed the way foreign policy was controlled by the head of the government, and since the unification of two German states - at least in the area of security policy - a strong society in Germany has had a significant impact on the decision-making process, including through elections, the creation of new party groups or demonstrations. The growing involvement of the Federal Republic in international organizations, in particular in the European Union, has also strengthened the 
autonomy of executive power over other entities (legislative and judicial). On the other hand, according to Harnisch, these actors seek increasingly to hedge the executive through procedural and normative demands in order to assert their own position in the decision-making process and their policy preferences (Harnisch, 2009, pp. 455-468).

From a liberal point of view, the distribution of foreign policy decisions has the following correlation with society as a whole or part of it: the wider the distributional effect, the more important the attitude of the entire population for the decision. The more the organization of an interest group is affected by distributional effects, the more the group will try to influence the state's policy.

Therefore, if we consider the German perspective on the BRI project and take into account the attitude of state and non-state actors in Germany (federal government, public opinion and mass media as well as interest groups) to the Belt and Road, two different phases can be distinguished:

1) in the first phase, which can be closed up in the years 2013-2016, mass media and public opinion - despite the considerable efforts of the Chinese government - remained indifferent to the BRI. Meanwhile, the attitude of the federal government was in principle positive, although Chancellor Angela Merkel herself and the cabinet members were quite modest in their statements; this phase lasted until the series of takeovers of German strategic companies by the Chinese;

2) in the second phase, which begun after the acquisition (or the attempts to do so) of the strategic German companies in 2016 and lasts till today, the situation has changed: on the one hand, Chinese investments in Germany and in many countries of Central and Eastern Europe had (and still have) an impact on existing infrastructural concepts created within the EU, which contributed to the implementation of the German initiative - the EU-China Connectivity Platform, a mechanism to avoid conflicts and develop a common position on bilateral issues using the synergy effect; on the other hand, the Federal Republic actively participated in the construction of the Asian Infrastructure Investment Bank (AIIB), signaling support for the development of the whole BRI. At the same time, the public opinion became more and more favourable in contacts with China, clearly indicating that the PRC is an attractive partner for Germany in both economic, political as well as cultural terms.

\section{First phase: fluctuation}

German public and social perception of the BRI project grew quite modestly. Only a few specialist publications (i.e. Godehardt, 2014, 2016; Rudolf, 2015, pp. 102-107) and press reports discussed the early phase of the project. The first important moment was the visit of Chinese President Xi Jinping in Duisburg in March 2014, which highlighted the importance of existing infrastructure initiatives, mainly rail connections (Leipzig-Shenyang 2011 and Duisburg-Chongqing 2012) (Cnotka, 2014). The actual involvement of German companies remained, at this early stage, strictly limited to the logistics sector and did not attract interest to the general public.

Also in October 2014, when 600 representatives of China's and European economy and politics gathered at the Hamburg summit, the Belt and Road Initiative was not yet 
in the center of interest of the German public opinion. Not surprisingly, during the joint meeting of the Chinese embassy in Berlin with the representatives of the Federal Ministry of Foreign Affairs in February 2016, the direct German concerns about the Chinese initiative were not discussed. The main issue was the compatibility of the BRI project with already existing economic communities - the Eurasian Economic Union and European Union.

An analysis of social attitudes in Germany towards China prepared at that time by Huawei Technologies, the largest Chinese company in Germany, showed a positive attitude of the Germans towards the People's Republic of China, but divergent values for bilateral political and economic relations and attitudes of the general public, business entities and political elites. The PRC was then seen as a global and dynamic economic power, but perceived with caution (or even with fear) by about half of all German respondents (49\%), including $43 \%$ of politicians and $51 \%$ of economic decision makers. More than every other German (60\%) believed that China's influence on the German economy is large or very large, while $35 \%$ of them believed that both countries benefit from technological cooperation. $58 \%$ of Germans also pointed out that domestic producers are being forced out of the market by Chinese producers. According to the survey results, China's growth in German media in 2014 was perceived as an opportunity rather than a threat to the German economy, and the importance of China was identified with the huge sales market for German products (Huawei, 2014). ${ }^{2}$

Looking at the reception of the Chinese initiative of the New Silk Road through the prism of public opinion, a slightly bigger attention can be found after 2014. The first climax was reached in spring 2015, when discussions about the German participation in building of the Asian Infrastructure Investment Bank, a competitive institution for the World Bank and the International Monetary Fund, flared up. AIIB was created in October 2014 and was headed by China. Its primary goal was to create incentives for investment growth in Asia, in transport as well as in energy, telecommunications or other infrastructure areas. Germany supported the creation of the bank with 4.5 billion USD and it was one of the largest shares among all member states (and the largest among countries outside the Asian region) (AIIB, 2015, pp. 30-31). It was a moment when in fact the Chinese initiative of the Belt and the Road began to be treated seriously in Germany not only in political and business circles, but also in the media, and public opinion became more interested in reports published by think tanks and foundations (Harnisch, 2017, p. 7).

The political nature of the analyzes in the first phase showed, above all, the chances for the German economy, but also the risks associated with the initiative. Questions were raised about the objectives of the Chinese concept - it was considered whether the goal is to build a far-reaching and coordinated infrastructure plan, or whether the $\mathrm{BRI}$ is a conglomerate of individual initiatives and activities, difficult to define pre-

${ }^{2}$ Huawei Technologies, in cooperation with the German Institute of Global and Area Studies (GIGA) and TNS Emnid, has been conducting research every two years on how China is perceived by the Germans and vice versa. The following areas are explored: "Interests and knowledge," "Policy and government," "Economy and innovation" and "Society and culture," and the analyzes are conducted on the basis of empirical findings and key statistical data. Print media monitoring is also carried out. 
cisely by Chinese economic interests. There has been speculation that the plan is motivated by geopolitical considerations based on Chinese influence in many regions of the world and at the same time, that it strives to use the existing Chinese surplus in individual sectors on regional markets without paying attention to causing distortions in local economies. However, the German media and experts were also aware that the initiative could and should have a stabilizing effect in the underdeveloped provinces of China and neighboring countries (Gaspers, Lang, 2016, p. 28).

Considering the social preferences (defined as cautious or skeptical towards the initiative) and the official attitude of the federal government, one can notice an evident discrepancy. Angela Merkel's cabinet supported the Belt and Road Initiative as early as October 2014, during the intergovernmental consultations organised in Berlin, and thus before the Chinese National Development and Reform Commission, the Ministry of Foreign Affairs and the Ministry of Trade jointly published the action plan "Perspectives and measures promoting the joint construction of the Silk Road and the Maritime Silk Road in the $21^{\text {st }}$ century" (April 2015) ${ }^{3}$ (Beijing Rundschau, 2015). The German Chancellor also stressed her government's position during her visit to Beijing in October 2015, when she praised the long-term strategic thinking of Chinese leaders in the development of the Silk Road initiative and called for a public debate on the impact of this infrastructure project, mentioning the need for intensive cooperation within the framework of the EU-China Connectivity Platform (Merkel, 2015).

\section{Second phase: conflict and cooperation}

Starting from 2016, a new economic dynamics was clearly visible, when Chinese investors launched an investment offensive in Europe, and in particular in Germany. The aforementioned takeover of shares in several strategic German enterprises meant that the political circles were becoming more and more skeptical about the steps taken by the Chinese partners. The problem of foreign acquisitions of German companies has been a source of concern for a long time. In 2016, Chinese companies announced or completed purchases of German companies with a total value of 11.3 billion EUR, and the involvement of Chinese government programs in these acquisitions, especially high-tech companies, caused criticism and extensive discussion on providing more access for German investors to the Chinese market. The effect of the shock associated primarily with the acquisition of Kuka Robotics by Midea, was the active lobbying of Germany for the introduction of control instruments for external entrepreneurs within the EU (Stanzel, 2017).

From that moment, the German government was determined to look critically at Chinese investments on the German market, which led to the failure of talks on the acquisition of Aixtron, a company manufacturing devices for the semiconductor indus-

${ }^{3}$ After the third intergovernmental consultations the federal government stated: "Germany welcomes the further expansion of transcontinental trade routes between Europe and China and the economic axis initiative along the Silk Road. This opens new opportunities for German-Chinese and Euro-Chinese cooperation and development services contributing to stability and prosperity in Central Asia and in countries along the route" (Bundesregierung, 2014). 
try; and Ledvance, a company belonging to the Osram lighting group. It was then that German politicians also began to speak out loud about the danger of buying Chinese companies from the key sectors of the German economy, and thus enabling them to reach strategic information on the latest technologies (Reuters, 2016).

In addition, the rapid growth of Chinese direct investment was assessed in Berlin as the reason for opening up the discussions on the accessibility of the Chinese market (including solar, chemical and steel industries) for European companies (Deutsche Welle, 2017). The direct consequence of this more decisive policy was the EuropeanChinese dispute during the Belt and Road Forum held in mid-May 2017 in Beijing (Pendrakowska, Bachulska, 2017).

Taking into account the German perspective, the real potential of conflict in the second phase is caused by the three distribution effects of the initiative for the EU and its eastern neighbours:

- Chinese infrastructure loans give strength to political entities both in the EU and its neighborhood (for instance through the 16+1 Initiative); their simultaneous consequence is the fact that Chinese investment activity may, but does not have to, stand in direct conflict with European Union standards and the terms of joining the Community (Przychodniak, 2017);

- Chinese credit-based infrastructure funds are quite attractive in some Central and Eastern European countries (Serbia, Hungary, the Czech Republic), which results in competition with EU programs. However, in the long term, the indebtedness of the countries of the region means that the People's Republic of China will have economic pressure to ensure that individual states follow the guidelines of China's foreign policy (Makocki, 2017);

- Chinese investments cause new political and economic distribution conflicts within the European Union. Growing dominance of Chinese investments in Europe poses EU the challenge of establishing EU mechanisms to strengthen the security system, especially in relation to cyber security and counterintelligence, and European regulations concerning Chinese investments. Meanwhile, during European Council meetings, the pressure of EU member states to resist solutions unfavorable for China, for instance in relation to creating a European investment control system, a key project for Chancellor Merkel, which was rejected in June 2017 due to pressure from Greece and the Czech Republic, is noticeable (Müller, 2018).

Considering the public opinion and media reports, the attitude of Germans towards China's economic power in the second phase is less alarming than it was before 2016. Comparing the results of the Huawei Technologies study conducted among German citizens as well as politicians and economic decision-makers, it can be stated that only $44 \%$ of the total population (compared to $49 \%$ in 2014) emphasizes reservations about China, while among politicians and entrepreneurs the fear of Chinese economic power dropped by about 1/3 (in the case of politicians in 2014 it was $43 \%$, and in $2016-35 \%$, while among businessmen in $2014-51 \%$, and in $2016-34 \%$ ). The survey showed that stereotypes are still strong in both societies - when asked about spontaneous associations, Chinese participants of the study answered that they associate Germans with "strong economy, automotive industry and German features," while thinking about China, many Germans indicated that this 
country provokes associations such as "economic strength, demographic growth and Chinese food" (Huawei, 2016).

It should be noted that the better perception of the BRI project by the Germans in the second phase (despite the undoubted challenges of selling shares of key companies) was related to increased access to scientific publications, a wide press offer, frequent media reports and political discussions connected with Chinese initiative and activity in Europe and in the world. After 2015, there were numerous specialist publications in German and English on various aspects of the BRI that presented a broad spectrum of Chinese foreign policy, including the concept of President Xi Jinping, Prime Minister Li Keqiang, Foreign Minister Wang Yi and other representatives of Chinese political life (Schüller, Schüler-Zhou, 2015; Stanzel, 2016; van der Putten et al., 2016; Ghiasy, Zhou, 2017; Pepe, 2017; Makocki, 2017; Schiek, 2017).

With the publication of the Joint Action Plan by the National Development and Reform Commission in spring 2015, the Belt and Road Initiative has entered its implementation phase. In addition to infrastructure changes, the BRI was supposed to include coordination of intergovernmental policy and undertake steps to increase trade and promote investment as well as people-to-people contacts (Miller, 2017). The Federal Association of German Industry (Bundesverband der Deutschen Industrie, BDI), the largest and most important association of the German economy, welcomed the initiative very warmly from the beginning. The result of opening to China became the establishment of the representative office by BDI in Beijing in mid-2017, which - according to the statement of the union - is able to not only take care of existing business contacts and seek new ones, but also to explain the emerging disputable situations (BDI, 2017). The German Chamber of Industry and Commerce (Deutscher Industrie- und Handelskammertag, DIHK) has similar positive opinions on the development of the German economy in China, and the chairman of the Munich Institute of Economic Research (ifo Institut - Leibniz-Institut für Wirtschaftsforschung), Clemens Fuest, claims that cooperation with the Chinese should be used by Germany as a lever to push for better investment conditions in the Middle Kingdom (Deutsche Welle, 2018).

Undoubtedly, Belt and Road is a project that offers completely new business opportunities, but it is interesting mainly for large corporations and companies classified as global players. For small and medium enterprises, it is often a challenge over and above strength. This is the reason why until now only a few German companies and institutions have taken seriously the implementation of the New Silk Road. Among them is Deutsche Bank, which has invested 3 billion EUR in AIIB; or German railways (Deutsche Bahn), which signed a contract to expand cooperation with Chinese state airlines in 2016. Also German transhipment centers such as Hamburg or Duisburg (DuisPort) expect new business opportunities due to the expansion of connections with sea and land routes created by the BRI.

However, research institutes and representatives of civil society argue that German-Chinese cooperation, even in the third markets (in Asia and Africa) is or will be problematic, because until now the initiative was not sufficiently balanced and did not have multilateral nature, so it will most likely lose acceptance in the destination countries. It is indicated that there are no knowledge exchange platforms that would allow the weaker countries to identify appropriate solutions, as well as set common 
standards for tendering and financing projects and rules for their links to existing strategies (Wolff, 2017).

In fact, in the second phase there is a mixed orientation of social preferences towards the Belt and Rod Initiative. Business-related institutes and companies emphasize the perspectives that this concept opens (especially in the Eurasian area) to German high-tech companies, specialist construction and logistics companies, and indicate broad sales opportunities in the European and Asian region. At the same time, they call for the opening of the EU internal market for Chinese investments to be conditional on the equal market opportunities for European companies in China because they have been insufficiently implemented so far, despite China's membership in the World Trade Organization (Majchrowska, 2014, pp. 206-215). Civil society organizations and research institutes criticize the insufficient participation of civic actors in the BRI target countries, which weakens the social, economic and environmental sustainability of this initiative.

Taking into account the position of the federal government towards the Belt and Road project, in the second phase, the Merkel's cabinet maintains its generally positive attitude towards the BRI and promotes the construction of the Asian Infrastructure Investment Bank - as the largest shareholder outside Asia, the Federal Republic supports the goals of sustainable development, which should be achieved by the bank through financing infrastructure and other production sectors. Representatives of the government are also in favor of linking the existing regional organizations and initiatives (e.g. $\mathrm{BRI}$ and Eurasian Economic Union) to achieve synergy in financing the infrastructural connection projects (Auswärtiges Amt, 2017a).

The federal government sees opportunities to cooperate with China primarily through partnership in the third countries. Large infrastructure projects require not only specialist knowledge that German companies have at their disposal, but also professional and independent risk assessment as well as active cooperation with existing institutions and financial organizations.

However, from the point of view of the federal government, over the past two years, it has become increasingly clear that Beijing is using its progressive investment activities not only in economic struggle, but also to exert political pressure and influence decisions on the EU member states as well as these aspiring to EU membership. This was particularly evident in the following cases: in summer 2016 Greece, Hungary and Croatia opposed the EU's common position calling on the Chinese government to comply with the decisions of the Permanent Court of Arbitration on Chinese territorial claims in the South China Sea (Gotev, 2016); in June 2017, a coalition of EU member states that has close investment relations with China (Greece, the Czech Republic, Portugal, Malta and Sweden) sought to prevent the introduction of stricter EU controls on foreign direct investment in Europe; in the same month Greece prevented the development of a common EU position on human rights violations in China $^{4}$ (Müller, 2018).

${ }^{4}$ Greece is increasingly supporting Chinese trade and investment because it faces the pressure of international creditors and, at the same time, can count on less support from the usual allies in Europe. In addition, China's largest shipping company, China COSCO Shipping, bought the majority stake in the Greek port of Piraeus in 2016. 
The reaction of the federal government to these events left little scope for interpretation. Germany's main concerns regard firstly China's efforts to break the unity of the Eurozone, and secondly, the Chinese expectations of a possible disintegration of the Community, which will change the international political situation and strengthen the position of the PRC (Pepe, 2017). These fears were the main topic of a widely discussed statement of Foreign Minister Sigmar Gabriel, who during the conference of French ambassadors in Paris on $30^{\text {th }}$ August 2017 said that EU members must conduct a common foreign policy towards China, otherwise "China will succeed in dividing Europe" (Gabriel, 2017). Gabriel argued that Beijing's cooperation with selected countries in Central and Eastern Europe as part of the Belt and Road Initiative is a threat to EU's unity and should therefore be countered. Referring to the multilateral cooperation agreement between the People's Republic of China and the CEE countries within the $16+1$ format, the German politician warned about China's great influence on European Union's policy and argued that the New Silk Road project was "a huge geopolitical, cultural, economic and undoubtedly also a military challenge" and it cannot be compared with the standards and values represented by Berlin and Brussels, and therefore should be counteracted (Gabriel, 2017).

The BRI is to be the next step of the PRC towards economic integration with the European Union, because the existing export and investment economy model in China is running out, and the New Silk Road may be an ideal tool for restructuring the current development formula. Wanting to find an outlet for surplus production, China is trying to implement numerous foreign investments, which will transfer into a new political dimension of China's global position. On the other hand, because it is still difficult to determine the ultimate goal of the Chinese project, German government circles indicate that the issues of transparency of cooperation and sustainable development should be a key to the success of the initiative. Department of Asia and the Pacific in the Federal Ministry of Foreign Affairs, established in May 2017, emphasizes that Germany is determined to cooperate with other partners in implementing the New Silk Road project, but at the same time counts on the synergy effect between the EU and China. However, this objective cannot be achieved at all costs, because the EU is based on transparent rules and cannot afford to neglect issues such as environmental protection, health and safety or social standards (OAV, Ebbighausen, 2017). According to the approach of German politicians, the idea of BRI will be valuable when all projects implemented within its framework will serve a sustainable development strategy that takes into account important economic and social aspects.

Thus, the perception of growing Chinese power is becoming more and more skeptical in the Federal Republic - it was so throughout the 2017, when the Vice-Chancellor and Foreign Minister S. Gabriel emphasized the need to create a common EU foreign policy towards China in his August-speech, what he also highlighted in the exposé entitled "Europe in an uncomfortable world" (Europa in einer unbequemeren Welt), presented on $5^{\text {th }}$ December 2017, when he said that the Belt and Road Initiative is a geostrategic idea that makes China enforce its vision of international order (Auswärtiges Amt, 2017b). At the same time, Chancellor A. Merkel became more and more distrustful, what was exemplified by her strong support for the amendment of the Federal Trade Regulation in July 2017, which hinders the acquisition of German companies operating in the know-how 
sector by foreign enterprises (BMWi, 2017), as well as her critical opinions expressed on the $16+1$ project, which is perceived in Berlin as a way of securing more Chinese investments in Europe and its wider neighborhood (Escritt, 2018).

This position did not change when, in March 2018, Angela Merkel took up the role of the German head of government for the fourth time. Likewise, the new Foreign Minister, Heiko Maas, believes that in troubled times Germany must assume greater responsibility for international politics, although he emphasizes that it should not overestimate its capabilities. Regarding China, Maas draws attention to the dialogue on human rights - as the Minister of Justice in the previous government, Maas has repeatedly emphasized the issue of non-respect of personal freedoms in China, hence it may be assumed that also as the head of diplomacy he will put a special emphasis on the issue of the rule of law (Rechtsstaatsdialog), which was introduced in German-Chinese relations in 2000. Although during the first meeting of the German Minister of Foreign Affairs with the head of the Chinese diplomacy Wang Yi in Berlin on 31 $1^{\text {st }}$ May 2018, both politicians discussed primarily the current international situation and economic affairs (i.a. the Korean Peninsula, Iran's issue, the protectionist policy of President D. Trump) (Auswärtiges Amt, 2018).

Also during the last, eleventh since taking the Chancellor's office, Merkel's visit to China (24-25 $5^{\text {th }}$ May 2018), the German head of government declared that both countries should intensify the cooperation at all levels and work on a "multilateral global system" based on supporting global free trade and seeking international solutions in crisis situations. During the meeting with President Xi, Merkel insisted on guaranteeing equal market access for German companies in China and emphasized that bilateral talks are used to identify problems and possibilities of solving them in areas such as technical development or cooperation in the field of finance and insurance (Bundesregierung, 2018).

To recapitulate, German foreign policy in the second phase indicates the following model: the increase of direct influence of the Chinese initiative on the preferences of many political, economic and civil society entities leads to a much stronger political reaction - Germany's accession to AIIB meant compatibility with the common German-Chinese economic and development policy interests in third countries (especially in Asia and Europe), while the demand for a single European policy towards the PRC by the Federal Minister of Foreign Affairs and the critical reaction of Chancellor Merkel, meant a lack of consensus on the political concepts presented by Berlin and Beijing, and different perception of shaping and coordinating EU internal policy. At the same time, with the establishment of the EU-China Connectivity Platform and with the conduction of in-depth intergovernmental dialogue, it becomes clear from a liberal point of view that both partners try to bring the process of shaping interests closer together through institutionalized policy coordination.

\section{Conclusion}

The analysis implies that Germany - through close cooperation with the PRC - wants to strive to maximize the benefits of the Belt and Road Initiative based on the synergy effect. It is also the declared position of China, which describes the BRI as an 
opportunity to build prosperity in Asia, the Middle East and Europe in accordance with the "win-win" principle.

For this purpose, Berlin can pursue the objectives of its international policy towards Beijing on several levels:

1) by supporting the involvement of German and European small and medium-sized enterprises in the process of developing the Belt and Road project, which could lead to a decrease in distrust in bi- and multilateral cooperation;

2) by coordinating the establishment of a committee regulating cross-border cooperation between China and the European Union and piloting projects aimed at creating a tripartite shareholding model (PRC, EU, non-EU-States) - in this way, an advanced German-Chinese cooperation could be implemented on the third-party markets;

3) by strengthening the dialogue within the EU-China Connectivity Platform and engaging in the emergence of a new form of cooperation, connecting both countries of the region, China and EU institutions, and supporting the creation of tripartite investment opportunities in selected areas.

Taking into account the perspective of the liberal theory in foreign policy, it should be noted that Germany's reaction to the New Silk Road cannot be adequately explained by power politics or the geo-economic approach. On the contrary, German political behavior especially in the second phase shows a dependence on social preferences, media reports and substantive analyses prepared by non-state actors.

For this reason, the liberal interpretation of Germany's ambivalent response is more convincing and empirically more credible than the political alternatives presented by realist theories - no other non-Asian country supported the construction of the Asian Infrastructure Investment Bank so strongly as Germany did, and no other European Union's country criticized the Chinese influence for internal voting processes in the Community as clearly as the Federal Republic. Conflicts between states are, from a liberal perspective, inevitable and they occur everywhere where the incompatibility of interests is so great that even institutionalized policy coordination - even through the EU-China Connectivity Platform - is not able to mitigate them. To avoid these conflicts, significant structural changes would have to be made on both sides, which would include the evolution of the Chinese investment approach in Europe (abandoning the dominant position of state-owned enterprises in business), but also the transformation of German interests in Central and Eastern Europe. Such changes are difficult to make in the near future, what leads to the conclusion that the ambivalent attitude of the Federal Republic of Germany will be continued and possibly strengthened or weakened, depending on political and social needs, requirements and expectations.

\section{Bibliography}

AIIB (2015), “Articles of Agreement - AIIB, ” Asian Infrastructure Investment Bank.

Auswärtiges Amt (2017a), "Eurasische Konnektivität”: Regionale Botschafterkonferenz im Auswärtigen Amt, 28.06.2017, https://www.auswaertiges-amt.de/de/aussenpolitik/regionaleschwerpunkte/asien/170622-eurasische-boko/290956, 20.02.2018. 
Auswärtiges Amt (2017b), Europa in einer unbequemeren Welt. Warum Europa eine neue Außenpolitik braucht - Rede von Außenminister Gabriel beim Forum Außenpolitik, https://www. auswaertiges-amt.de/de/newsroom/berliner-forum-aussenpolitik/746464, 10.12.2017.

Auswärtiges Amt (2018), Protektionismus und Abschottung dürfen nicht die Oberhand gewinnen, 31.05.2018, https://www.auswaertiges-amt.de/de/aussenpolitik/laender/china-node/maaschina-welthandel-/2099996, 10.06.2018.

BDI (2017), “Wir wollen das China sich öffnet,” BDI-Agenda 2017/06, 07.06.2017, https://bdi.eu/ newsletter/agenda/issue-2017-06-17/wir-wollen-nicht-dass-europa-sich-abschottet-wir-wollen-dass-china-sich-oeffnet, 30.05.2018.

Beijing Rundschau (2015), Chronik März 2015, http://german.beijingreview.com.cn/Dossiers/ydyl/ Chronik/201704/t20170425_800094632.html, 25.06.2018.

Bērziņa-Čerenkova U. A. (2016), BRI Instead of OBOR - China Edits the English Name of its Most Ambitious International Project, http://www.lai.lv/viedokli/bri-instead-of-obor-china-editsthe-english-name-of-its-most-ambitious-international-project-53, 28.02.2018.

BMWi (2017), Verordnung der Bundesregierung. Neunte Verordnung zur Änderung der Außenwirtschaftsverordnung, Bundesministerium für Wirtschaft und Energie, http://www. bmwi.de/Redaktion/DE/Pressemitteilungen/2017/20170712-zypries-besserer-schutz-beifirmenuebernahmen.html, 20.12.2018.

Brummer K., Oppermann K. (2014), Außenpolitikanalyse, München, Oldenbourg.

Bundesregierung (2014), Aktionsrahmen für die deutsch-chinesische Zusammenarbeit: "Innovation gemeinsam gestalten!, ” Presse- und Informationsamt der Bundesregierung, 10.10.2014, http://www.bundesregierung.de/Content/DE/_Anlagen/2014/10/2014-10-10-aktionsrahmen-dt- chin.pdf?_blob=publicationFile\&v=1, 17.03.2018.

Bundesregierung (2018), Pressestatement von Bundeskanzlerin Merkel zum Abschluss der Reise nach China, 25.05.2018, https://www.bundesregierung.de/Content/DE/Mitschrift/ Pressekonferenzen/2018/05/2018-05-25-merkel-statement-shenzhen.html, 10.06.2018.

Campbell C. (2017), China Says It's Building the New Silk Road. Here Are Five Things to Know Ahead of a Key Summit, 12.05.2017, http://time.com/4776845/china-xi-jinping-belt-roadinitiative-obor/, 28.02.2018.

Cnotka D. (2014), Großer Bahnhof für Xi Jinping, "Westdeutsche Allgemeine Zeitung," 31.03.2014, https://www.waz.de/staedte/duisburg/grosser-bahnhof-fuer-xi-jinping-id9184012.html, 15.03.2018.

Dams J., Grabitz I. (2018), Deutschland wird zwischen zwei Giganten zerrieben, "Die Welt," 03.03.2018.

Deutsche Welle (2017), Was bringt Chinas Neue Seidenstraße?, 17.11.2017, http://www.dw.com/de/ was-bringt-chinas-neue-seidenstra\%C3\%9Fe/a-41421445, 20.02.2018.

Deutsche Welle (2018), Schwelende Handelskonflikte verunsichern Unternehmer, 25.06.2018, https://www.dw.com/de/schwelende-handelskonflikte-verunsichern-unternehmer/a44378746, 27.06.2018.

dpa (2016), Chinesen starten größte Übernahme in Deutschland, "Der Spiegel," 4.02.2016, http:// www.spiegel.de/wirtschaft/unternehmen/eew-chinesen-kaufen-deutschen-abfallkonzern-a1075662.html, 23.06.2018.

Escritt T. (2018), China Investment Must Not Undermine EU Joint Policy, Warns Merkel, https://www. nytimes.com/reuters/2018/02/27/business/27reuters-china-europe-merkel.html, 20.04.2018.

EY (2018), Chinesische Unternehmenskäufe in Europa. Eine Analyse von M\&A-Deals 2006-2017, Januar.

Gabriel S. (2017), Rede des Bundesministers des Auswärtigen, Sigmar Gabriel, bei der 25. französischen Botschafterkonferenz am 30. August 2017 in Paris, "Bulletin der Bundesregierung," no. 91-1, 6.09.2017. 
Gaspers J., Lang B. (2016), Germany and the Belt and Road Initiative: Tackling Geopolitical Implications through Multilateral frameworks, in: Europe and China's New Silk Roads, eds. van der Putten et al., ETNC Report, December.

Ghiasy R., Zhou J. (2017), The Silk Road Economic Belt. Considering security implications and EUChina cooperation prospect, SIPRI, https:/www.sipri.org/sites/default/files/The-Silk-RoadEconomic-Belt.pdf, 20.02.2018.

Godehardt N. (2014), Chinas »neue" Seidenstraßeninitiative Regionale Nachbarschaft als Kern der chinesischen Außenpolitik unter Xi Jinping, SWP, https://www.swp-berlin.org/fileadmin/ contents/products/studien/2014_S09_gdh.pdf, 12.03.2018.

Godehardt N. (2016), No End of History. A Chinese Alternative Concept of International Order?, SWP, https://www.swp-berlin.org/fileadmin/contents/products/research_papers/2016RP02_ gdh.pdf, 12.03.2018.

Gotev G. (2016), EU unable to adopt statement upholding South China Sea ruling, 14.07.2016, http://www.euractiv.com/section/global-europe/news/eu-unable-to-adopt-statement-upholding-south-china-sea-ruling/, 20.02.2018.

Hanemann T., Huotari M. (2017), Record Flows and Growing Imbalances. Chinese Investment in Europe in 2016, MERICS Papers on China, no. 3.

Harnisch S. (2009), German Politics Lecture: The politics of domestication: A New Paradigm in German foreign policy, "German Politics," no. 18/4.

Harnisch S. (2017), Deutschlands Politik gegenüber der Belt-and-Road-Initiative der Volksrepublik China 2013-2018, Beitrag für die Zeitschrift “Asien” der Deutschen Gesellschaft für Asienkunde, e.V.

Harnisch S. (2006), Internationale Politik und Verfassung. Zur Domestizierung des sicherheits- und europapolitischen Prozesses der Bundesrepublik Deutschland, Baden-Baden.

Huawei (Hrsg. in Zusammenarbeit mit dem GIGA und TNS Emnid) (2014), Deutschland und China - Wahrnehmung und Realität. Die Huawei-Studie 2014, http://www.huawei-studie.de/downloads/Huawei-Studie-2014-DE.pdf, 15.11.2017.

Huawei (Hrsg. in Zusammenarbeit mit dem GIGA, Universität Duisburg-Essen und TNS Emnid) (2016), Deutschland und China - Wahrnehmung und Realität, Die Huawei-Studie 2016, http://www.huawei-studie.de/downloads/Huawei-Studie-2016-DE.pdf, 20.02.2018.

Kundnani H. (2011), Germany as a Geo-economic Power, "The Washington Quarterly," Summer.

Lu F., Anchetta A. (2015), Taicang promotes the Belt and Road Initiative, 03.06.2015, China Daily, http://www.chinadaily.com.cn/regional/2015-06/03/content_20902044_2.htm, 15.03.2018.

Majchrowska E. (2014), Wpływ członkostwa w WTO na handel zagraniczny Chin. Implikacje dla gospodarki światowej, Kraków.

Makocki M. (2017), China in the Balkans: The Battle of Principles, European Council on Foreign Relations, http://www.ecfr.eu/article/commentary_china_in_the_balkans_the_battle_of_principles_721, 12.02.2018.

Merkel A. (2015), Rede von Bundeskanzlerin Merkel beim Bergedorfer Gesprächskreis am 29. Oktober 2015, 29.10.2015, https://www.bundesregierung.de/Content/DE/Rede/2015/10/2015-1029-rede-merkel-bergedorfer-gespraechskreis.html, 30.02.2018.

Miller T. (2017), China's Asian Dream: Empire Building along the New Silk Road, London.

Moravcsik A. (1997), Taking Preferences Seriously: A Liberal Theory of International Politics, "International Organization," no. 51, Autumn.

Moravcsik A. (2008), The New Liberalism, in: The Oxford Handbook of International Relations, eds. C. Reus-Smit, D. Snidal, New York, Oxford.

Müller P. (2018), Neue Studie: Wie China die EU unterwandert, "Der Spiegel," 3.02.2018, http:// www.spiegel.de/spiegel/europaeische-union-eine-studie-zeigt-wie-china-die-eu-unterwandert-a-1191056.html, 17.03.2018. 
OAV, Ebbighausen R. (2017), Die deutsche Sicht aufChinas Seidenstraße, https://www.oav.de/ueberuns/oav-pressespiegel/pressebericht-lesen/die-deutsche-sicht-auf-chinas-seidenstrasse.html, 17.04.2018.

Pendrakowska P., Bachulska A. (2017), Forum Pasa i Szlaku w kontekście międzynarodowym, “Analiza Centrum Studiów Polska-Azja," no. 12, 27.05.2017, http://www.polska-azja.pl/ analiza-cspa-12-forum-pasa-i-szlaku-w-kontekscie-miedzynarodowym/, 23.06.2018.

Pepe J. M. (2017), China's Inroads into Central, Eastern and South Eastern Europe. Regional and Global Implications for Germany and the EU, "DGAP Analyse," no. 3.

Popławski K. (2017), Kapitał ma narodowość: obawy w Niemczech wobec chińskich inwestycji, "Komentarze OSW," no. 230.

Przychodniak M. (2017), Inicjatywa 16+1 i wyzwania dla wspólpracy Chin z Europa ŚrodkowoWschodnia, "Biuletyn PISM," no. 121, 5.12.2017, https:/www.pism.pl/publikacje/biuletyn/ nr-121-1563, 23.06.2018.

Reuters (2016), Germany stalls Osram unit sale to Chinese buyers, 27.10.2016, https://de.reuters. com/article/osram-licht-ma-idUKL8N1CX72E?type=companyNews, 12.06.2018.

Risse-Kappen T. (1991), Public Opinion, Domestic Structure, and Foreign Policy in Liberal Democracies, "World Politics," no. 43/4.

Rudolf M. (2015), Häfen, Bahnen, Pipelines, "Internationale Politik,” no. 63/3.

Schiek S. (2017), Bewegung auf der Seidenstraße. Chinas Belt and Road-Initiative als Anreiz für zwischenstaatliche Kooperation und Reformen an Zentralasiens Grenzen, SWP, https:// www.swp-berlin.org/fileadmin/contents/products/studien/2017S16_ses.pdf, 20.02.2018.

Schüller M., Schüler-Zhou Y. (2015), Chinas Seidenstraßen-Initiative trifft auf transeuropäische Infrastrukturpolitik, "GIGA-Focus," no. 8, https://www.giga-hamburg.de/de/system/files/ publications/gf_asien_1508_0.pdf, 20.03.2018.

Stanzel A. (2016), China's Investment in Influence: The Future of 16+1 Cooperation, China Analysis, European Council on Foreign Relations, http://www.ecfr.eu/page/-/China_Analysis_Sixteen_Plus_One.pdf, 12.02.2018.

Wolff P. (2017), Chinas Seidenstraßen-Initiative in der Sackgasse?, 19.05.2017, https://bonnsustainabilityportal.de/de/2017/05/wolff-peter-die-is-chinas-silk-road-initiative-at-a-dead-end/, 20.05.2018.

Wübbeke J., Meissner M., Zenglein M. J., Ives J., Conrad B. (2016), Made in China 2025: The making of a high-tech superpower and consequences for industrial countries, Mercator Institute of China Studies, December, no. 2, https://www.merics.org/index.php/en/papers-on-china/ made-china-2025, 20.05.2018.

\section{Summary}

The People's Republic of China has achieved the position of one of the major players in the international arena and is boldly pursuing the policy of foreign expansion. Its basic instrument is the Belt and Road Initiative (BRI), which in recent years has been one of the most important projects of the Chinese authorities, assuming the intensification of economic cooperation and cultural exchange of countries along the New Silk Road. Germany, the EU leading state and China's crucial partner in Europe, is a strong supporter of the Belt and Road Initiative. However, as the concept of BRI involves the member states of the European Union, it also requires a strong reaction from the Community. And although the EU's relations with the PRC are in the economic interest of all its member states, they have not been without complications in recent years.

The paper examines the importance of societal preferences and attitudes of the Federal Republic of Germany towards the Belt and Road Initiative since 2013 by using the liberal explana- 
tory approach. The aim of the paper is to analyse the German response to the Silk Road project in two distinct phases: the first one (2013-2016) and the second phase (2016-). Moreover the article will try to identify the problems that exist in relations between the European Union and China, with particular emphasis on the relations between the People's Republic of China and the Federal Republic of Germany. A short theoretical conclusion as well as political recommendations conclude the analysis.

Key words: Germany, China, cooperation, Belt and Road Initiative, New Silk Road

\section{Chińska Inicjatywa Pasa i Szlaku - perspektywa Republiki Federalnej Niemiec}

\section{Streszczenie}

Chińska Republika Ludowa osiągnęła pozycję jednego z głównych graczy na arenie międzynarodowej i odważnie realizuje politykę ekspansji zagranicznej. Jej podstawowym instrumentem jest inicjatywa Pasa i Szlaku (Belt and Road Initiative, BRI), która w ostatnich latach jest jednym z najważniejszych projektów chińskich władz, zakładającym zintensyfikowanie współpracy gospodarczej i wymianę kulturalną krajów wzdłuż Nowego Jedwabnego Szlaku. Niemcy, czołowe państwo UE i kluczowy partner Chin w Europie, są silnym zwolennikiem inicjatywy BRI. Ponieważ jednak koncepcja ta obejmuje państwa członkowskie Unii Europejskiej, wymaga również silnej reakcji ze strony Wspólnoty. I chociaż stosunki UE z ChRL leżą w interesie gospodarczym wszystkich jej państw członkowskich, w ostatnich latach nie były one wolne od komplikacji.

Artykuł analizuje znaczenie społecznego postrzegania i postaw aktorów państwowych Republiki Federalnej Niemiec wobec projektu Pasa i Szlaku od 2013 r., stosując liberalne podejście wyjaśniające. Celem artykułu jest przeanalizowanie reakcji Niemiec na inicjatywę Nowego Jedwabnego Szlaku w dwóch różnych fazach: pierwszej (2013-2016) i drugiej fazie (2016-), w której wypracowano model współpracy i świadomość występujących konfliktów. Ponadto artykuł próbuje zidentyfikować problemy istniejące w stosunkach między Unią Europejską a Chinami, ze szczególnym naciskiem na stosunki między Chińską Republiką Ludową a Republiką Federalną Niemiec. Analizę kończą krótki wniosek teoretyczny oraz rekomendacje polityczne.

Słowa kluczowe: Niemcy, Chiny, współpraca, Inicjatywa Pasa i Szlaku, Nowy Jedwabny Szlak 
